CURRENT DEVELOPMENTS IN ECONOMICS 


\section{Current Developments in Economics}

STEPHEN C. R. MUNDAY

Foreword by G. C. Harcourt

2

Macmillan Education 
ISBN 978-0-333-64444-7 ISBN 978-1-349-24986-2 (eBook)

DOI $10.1007 / 978-1-349-24986-2$

CURRENT DEVELOPMENTS IN ECONOMICS

Copyright (C) 1996 by Stephen C. R. Munday

Foreword copyright $\odot$ by G. C. Harcourt

Softcover reprint of the hardcover 1st edition 1996 978-0-333-64443-0

All rights reserved. No part of this book may be used or reproduced

in any manner whatsoever without written permission except in the

case of brief quotations embodied in critical articles or reviews.

For information, address:

St. Martin's Press, Scholarly and Reference Division, 175 Fifth Avenue, New York, N.Y. 10010

First published in the United States of America in 1996

ISBN 978-0-312-16338-9 (cloth)

ISBN 978-0-312-16339-6 (paperback)

Library of Congress Cataloging-in-Publication Data

Munday, Stephen C. R., 1964

Current developments in economics / Stephen C. R. Munday.

p. $\mathrm{cm}$.

Includes bibliographical references and index.

ISBN 978-0-312-16338-9 (cloth : alk. paper). — ISBN 978-0-312-16339-6

(pbk.)

1. Economics. 2. Economics-Methodology. 3. Economics-History.

4. Economic policy. I. Title.

HB 171.5.M934 1996

$330-\mathrm{dc} 20$

$96-21861$

CIP 
To all those who have instructed and inspired me in the ways of the 'dismal science', especially Ray 'The Chief' Jarvis, Jeremy Edwards and Geoff Harcourt. With thanks. 


\section{Contents}

Foreword by G.C. Harcourt $\quad \mathrm{x}$

Acknowledgements $\quad$ xi

Introduction $\quad$ xiii

PART I AN OVERVIEW OF ECONOMICS 1

1 Economic Methodology or How To Do Economics 3

A consideration of the method, or practice, of economics, as opposed to its subject content.

2 A Brief History of Economic Thought

An overview of the history of economic thought, pinpointing key individuals and themes and suggesting their importance for the study of economics today.

3 Microeconomics and Macroeconomics

A consideration of the various possible important links to the two halves of economics, as traditionally divided.

\section{PART II DEVELOPMENTS IN MICROECONOMICS}

4 Game Theory and Its Uses

An overview of game theory as used in economics and a consideration of its various possible applications.

5 Privatisation

A consideration of the economic arguments for and against privatisation. Does competition imply efficiency? The theory of contestable markets. A case study of British Rail.

A consideration of the economic theory of regulation. OFTEL is a case study.

6 Economic Theory and the Environment

The relevant economic theory to a consideration of the problems of environmental damage. The implied government policies are discussed. Global warming and toxic waste are taken as case studies. 
7 Government Provision of Services: Health Care and Education

An overview of the case for the free market provision of all goods and services, followed by a consideration of both market and government failure and their implications for government policy. The topical applications are to health care and education.

8 Taxation

A consideration of the economic justification for a government raising taxes. What criteria dictate whether a tax is good or bad? The theory of optimal taxation. The implications of the theory of optimal taxation for taxing commodities and income and for the debate concerning charging for admission to museums.

9 International Trade: Old Theories, New Theories and the Single European Market

A look at the theory of comparative advantage and its shortcomings in explaining today's trade flows. New trade theories with their possible implications for restricting trade. How the Single Market in Europe fits in with the differing theories.

\section{PART III DEVELOPMENTS IN MACROECONOMICS}

10 Macroeconomic Models

A look at the three different macroeconomic models used in textbooks: the 45 degree diagram, the ISLM model, and aggregate supply and demand. What are the key policy issues in macroeconomics that they emphasise?

11 Unemployment, Inflation and the Phillips Curve

A look at all new developments in the theories of the two key macroeconomic variables of unemployment and inflation. What do they appear to imply for the Phillips curve and for government policy?

12 Exchange Rates and Economic and Monetary Union

A look at the arguments for and against fixed exchange rates and the theory of optimal currency areas. What do these imply for Economic and Monetary Union in Europe?

13 Economics and Politics: Political Business Cycles and Independent Central Banks

A consideration of the axioms of economics for the practice of politics. Two important applications, the political business cycle and independent central banks, are discussed. 
14 Economic Growth: Old Theories, New Theories and Government Policy

A look at the traditional theories of economic growth followed by an overview of the new theories of economic growth with their emphasis on positive externalities. What are the implications for government policy?

\section{Conclusion}

Index 


\section{Foreword}

Teaching economics well at any level is a great challenge and at an introductory level probably the greatest challenge of all. To achieve effective success, the reading set needs to be authoritative, balanced, lucid, applicable to the world around us, especially as perceived by the students involved, and exciting and inspirational. By writing down this list, I have described Stephen Munday's splendid Current Developments in Economics.

I had the privilege, first, of lecturing to Stephen when he was a student at Cambridge in the 1980s (I also played cricket against him), and secondly, of seeing a lot of him and of reading his book in embryo when he was school teacher bye fellow at Selwyn in 1994. I learnt a great deal from all these encounters.

Stephen really is the master of his subject. His range is wide; he sees his subject as a means to understand the world, why it works well and badly, and what may be done about it. He is a humane and generous person and these traits inform all that he does and writes. He has a good sense of the nature of political constraints and of the limitations of economic analysis itself. Within these constraints, he has written a book which guides the reader, carefully and with mounting enthusiasm, through current developments in economic analysis and their applications to the pressing economic and social problems of our age. I cannot recommend too highly this excellent introduction to what is still a fine calling, worthy of the attention of all those with cool heads and warm hearts, as Marshall put it long ago, who care about their fellow citizens and their society.

G.C. HARCOURT

Reader in the History of Economic Theory

Fellow, Jesus College, Cambridge

Professor Emeritus, University of Adelaide 


\section{Acknowledgements}

There are many people who have enabled the writing and publication of this book. I am grateful to all of them.

I was afforded the opportunity to research for the book through a term's leave granted to me by the headmaster and governors of Bishop's Stortford High School. I then spent a wonderful term as schoolteacher bye-fellow at Selwyn College, Cambridge. This must be the friendliest of all the Cambridge colleges, and I am most appreciative of all the fellows who made my term so enjoyable, and especially to the advice and encouragement of both Mica Pani!c and Max Beber. I was fortunate also to renew acquaintance with Geoff Harcourt, who gave much helpful advice and encouragement on the research for this book.

I am very grateful to Tony Thirlwall for commenting extensively on some early proposals that I had about the book and for the several various helpful suggestions that he made about its structure and content.

During my research I found particular books and articles especially helpful for different topics. The Oxford Review of Economic Policy is an outstanding economics journal, and I found the review articles on several of the topics that I was handling particularly helpful. I would recommend them to anyone studying economics. Robert Heilbroner's The Wordly Philosophers is an excellent summary of the thoughts and ideas of most major economists, and I found the book particularly helpful for the chapter on the history of economic thought. Geoff Harcourt's lecture notes on the topic were also very useful. I found Bronwyn Croxson's lecture notes on the economics of health care particularly helpful for the chapter on the state provision of goods and services.

I am grateful to the Brookings Institution for permission to use the table on the estimated effects of inflation and unemployment upon government popularity in the chapter on economics and politics.

Both Stephen Rutt and Nicola Young at Macmillan have been friendly and helpful and I am grateful to them for their editorial work.

Finally, I owe a great debt of gratitude to my two young daughters and especially my wife, Elizabeth. I sometimes wondered if the opportunity cost of the project was too great and without Elizabeth's tolerance and encouragement the book could never have come into existence. Thank you.

STEPHEN C.R. MUNDAY 


\section{Introduction}

This book aims to be an economics textbook with a difference. It does not aim at anything approaching universal coverage of the subject matter of economics. Topics such as the basis of supply and demand theory and the different competitive models in the theory of the firm are hardly mentioned. As such, it is in no way intended to be a substitute for a sound, basic economics textbook. Rather, it is designed to complement such texts. The purpose is to pick on issues within economics that either are often insufficiently covered or entirely neglected in many of the standard textbooks, or where there have been important new developments in the relevant economic theory which have generally not found their way into the textbooks. Often, such developments occupy much space in the standard economic journals and form an important part of many economics and related subjects degree courses. However, they are rarely found in a general textbook. The aim of the book is thus to bridge that gap.

Within that overall aim, this book has certain other principles. The general approach of each chapter is to take a topic of interest and importance in the study of any economics course. The relevant theory concerning that issue is then explained, often with two sections, one summarising what might today be called the 'traditional' economic theory and the other then considering relevant new theory in that area. Once this is done, topical case studies are chosen to which it is possible to apply the relevant theory. Where possible, the implications for government economic policy are also considered. The suggestion is thus that the economist can arm himself or herself with certain important principles and theories which can be used as a lens with which to view a whole host of important issues in order to aid understanding and analysis. The book also aims not to use any mathematical language. The logic and significance of the theories in economics can be appreciated without having to be expressed in a language that remains foreign to many who endeavour to study the subject of economics. Thus those who are uncomfortable with mathematics should be entirely comfortable with the approach of this book (as indeed should those who do feel comfortable with mathematics!).

The book is divided into three separate sections. Part I, an overview of economics, is in some ways an introduction, but more a look at three overarching fundamental issues in the study of economics which are generally virtually entirely ignored in most standard economics textbooks. The first concerns economic methodology (Chapter 1). The general tendency is to dive into the subject content of economics without considering how the subject should be studied and used. This chapter looks at the issues involved. Chapter 2 attempts the ambitious task of giving a brief overview of the history of economic thought. So often economic theory and practice is better and more fully appreciated within its his- 
torical perspective, yet this is equally often simply ignored. Chapter 3 addresses the standard divide in the subject of economics between microeconomics and macroeconomics. Usually, the difference between these is defined in economics textbooks, and then they are treated as almost entirely separate subjects. The problems with this are discussed, as are the reasons why the two must be seen as a coherent whole.

Part II of the book picks on various topical issues within the subject of economics which are usually seen as part of microeconomics. Game theory has received great attention in the study of economics in recent years, but little of this has found its way into the standard economics textbooks. Chapter 4 attempts to overcome that problem. Privatisation is an issue that does appear in many textbooks, but Chapter 5 here looks at relevant theory that is less frequently considered and discusses how its application is relevant to the topic. The environment is an issue of particular current concern. There is much important and relevant economic theory that can be applied here, and that is what Chapter 6 attempts to do. Consideration of the rationale of the government provision of goods and services goes to the heart of important theory and theoretical differences within economics. The whole range of relevant economic theory, both old and new, is considered and applied to the topics of health care and education in Chapter 7. Taxation is a political hot potato, but Chapter 8 on this topic looks at how a proper understanding of the relevant economic theories can help to clarify and to understand what are the important issues at stake. finally, Chapter 9 on the economics of trade looks at new trade theories that challenge the standard theories of trade which form the usual presentation of economics textbooks.

The final section of the book, Part III, examines some of the fundamental and topical issues within the area of macroeconomics. All standard textbooks look at some or all of the macroeconomic models that are available for studying the subject. However, the purpose of Chapter 10 is to put the different models side by side and to consider which issues are best understood through which models, and what are the shortcomings of each of the models. Chapter 11 on inflation, unemployment and the Phillips curve attempts an overview of these related fundamental topics within macroeconomics. As such, it is more of a general chapter than many of the others which pick on particular, tighter themes. However, understanding the issues here is fundamental to understanding the study of macroeconomics. New developments and their implications are considered wherever they are relevant. Chapter 12 on economic and monetary union looks at general theory in this area to try to clarify the issues. In particular, an understanding of optimal currency areas is important. Public choice theory is hardly dealt with in the standard textbooks, but it is an important area of economic theory and helps to understand the issues behind political business cycles and independent central banks. Chapter 13 investigates this. finally, Chapter 14 on economic growth suggests that a greater prominence should be given to this area of economic theory in textbooks and explains important recent theoretical developments in this area. 